\title{
Good Governance and Agricultural Efficiency
}

\author{
*Nizamettin Bayyurt, Zehra Vildan Serin, Fatma Eban Arıkan \\ Fatih University, Istanbul, Turkey \\ *bayyurt@fatih.edu.tr
}

\begin{abstract}
This study aims to understand the effects governance indicators on the agricultural efficiency using European countries as a tool. It focuses on the efficiency of EU countries together with Turkey. In the first stage Data Envelopment Analysis and Malmquist Index are used to derive efficiency scores and the Total Productivity Change in time for 24 countries during the study period. A panel data Tobit regression is employed in the second stage to assess the key governance indicators explaining the observed variations in the efficiency levels. Four governance indicators namely, voice and accountability control of corruption, government effectiveness and regulatory quality together with the control variables; agricultural exports, education, research and development expenditures are analyzed in this stage. Findings show that the average efficiency of EU countries was slightly increased during the study period. The impact of voice and accountability, the share of R\&D in GDP and the share of food products in exports upon the agricultural efficiency are positive whereas the impacts of the share of GDP allocated to education upon agricultural efficiency is negative.
\end{abstract}

Keywords: Agriculture, EU, Efficiency, Governance, DEA

\section{Introduction}

The EU agricultural policy is among the most debated policies as it takes the biggest share from the EU budget. It has been widely underlined that it needs reforms and its productivity should be enhanced. While the share of agricultural expenditures in the total budget was nearly $70 \%$ in the 1970s, it is planned for the period 2007-2013 to reduce it to 34\% through reforms (Marković et al., 2012). After intensive negotiations in 2013, the new CAP 2014-2020 which has been approved by the Council and the European parliament with a lower budget than proposed by the Commission These reforms focus on both reducing costs and enhancing productivity (European Commission, 2014). The agriculture industry is of importance not only for developing countries but also for developed countries as it is the main provider of food and raw materials and it creates employment. Globalization and ongoing structural transformations have impacts upon the agricultural policies of the EU and Turkey. Enhancing the productivity of agriculture is among the most important problems of the entire world. High food prices along with climate changes, civil wars and the global financial crisis have brought about numerous serious problems pertaining to access to food and food safety such as hunger and malnutrition. Therefore, the primary among the United Nations' targets for the year 2015 is "combating hunger and poverty" (Adebayo et al, 2014).

Although a decline had been observed in the number of the malnourished in the world from the 1970s to 1997, the number has increased gradually after this year. Following the 2007 crisis, price indexes of many agricultural products, particularly sugar, have risen. The food price crisis, experienced globally between 2007 and 2009, was followed by the global economic crisis. Developments of the recent years have dramatically demonstrated the importance of ensuring food safety, access to food and thus productivity in agriculture. Governance has become a hot topic on the critical role it plays in determining social welfare. There are lots of studies in literature concerning agricultural productivity. And also in recent years it has begun to realize that good governance significantly influences a country's agricultural productivity. For all these reasons, this study aims to examine the productivity of agriculture in the European Union and the effects of governance on the agricultural efficiency. Even though Turkey is not a member of EU yet, it is a big agricultural product supplier and candidate for EU membership, it is included in the analysis. Data Envelopment Analysis (DEA), Malmquist Index (MI) and regression analysis were employed. We find agricultural efficiency scores and efficiency changes in time of 24 EU countries with DEA and MI. Then, using the efficiency scores of the countries and governance indicators as well as some control variables a panel regression analysis was executed. The indicators of governance used in the study are developed by Kaufman et al. (2006a). 


\section{Literature Review}

The subject of productivity in agriculture has been addressed by some theoretical and practical studies from different perspectives. Lio and Hu (2009), in their study on the years of 1996, 1998, 2000 and 2002, investigated whether there exists a correlation between agricultural efficiency and governance indicators. Improvements in rule of law, control of corruption and government effectiveness enhance agricultural productivity significantly. According to the findings of this study, poorer countries can considerably increase their agricultural efficiency by strengthening the state and citizens' respect for institutional framework. Yet another important finding is that more democratic countries had lower agricultural production efficiency rates. Méon and Weill (2005) used a sample consisting of 62 countries in order to test the relationship of six indicators with governance. When these six indicators were included in the inefficiency model, it was observed that only government effectiveness is significant; while political stability, control of corruption and quality of regulations are not.

Minh and Long (2008) analyzed the technical efficiency of agricultural production in 60 regions of Vietnam between the years of 1990 and 2005 through DEA. Serrao (2003) measured the agricultural productivity in 14 EU countries and four Eastern European countries for the period 1980-1998 using DEA and found good performances for Germany, Belgium and Luxembourg. Hungary had the lowest total factor productivity; it had a low efficiency and no difference between its regions. Davidova et al. (2005) compared the productivities and profitabilities of farms in Czech Republic, Hungary and Poland. It was found, based on the questionnaire results, that Hungarian farms exhibit the best performance in terms of profitability. In Poland, on the other hand, profitability is low and structural problems are bigger. Family farms in Czech Republic and Hungary are less productive than corporate farms. Kaya and Avcr (2008) examined the agricultural productivity in 24 transition economies including Turkey for the period between 1994 and 2004. In this study, while Turkey's value of change in technical efficiency remained the same as the average of other countries, its value of technological change lagged behind others. Turkey's total factor productivity was also lower than the average of other countries.

Kaufman et al. (2006a) have developed six indicators of governance: rule of law, control of corruption, government effectiveness, regulatory quality, accountability and political stability. Kaufmann et al. (2006b) developed a function consisting of external variables, which are governance variables that explain agricultural efficiency differences between countries. The representative variables, that represented governance infrastructure, were developed in this study of Kaufmann that was on 199 countries covering the years of 1996, 1998, 2000 and 20021. Adkins et al. (2002) examined the impacts of the institutional variables of economic liberty, political rights and civil freedoms upon macroeconomic efficiency in 76 countries for the years of 1975, 1980, 1985; and found that economic liberty is of importance along with technical efficiency, whereas the impacts of political rights and civil freedoms are not significant. Arnade (1994) examined international agricultural productivity. Zaim et al. (2001) analyzed the agricultural productivity and its factors on the basis of provinces and regions in Turkey for the period of 1990-1996. Deliktaş et al. (2005) examined the relative efficiencies and total factor productivity indexes of agriculture industries of Turkey and 14 EU countries for the period 1980-2002 using Data Envelopment Analysis (DEA). They observed advancement in technology and a decline in efficiency. Çakmak et al. (2008) investigated the changes in efficiency of the agriculture sector on the basis of the regions of Turkey. Bayyurt and Yllmaz (2012) analyzed the impacts of governance and education on agricultural efficiency in a global context and they found that while regulatory quality has a positive effect on agricultural efficiency education has negative effects.

Hypothesis Development: Governance affects agricultural productivity in many ways. Firstly, bad governance influences the taxes collected on manufacturing activities. Not only does it cause the accumulation of less efficient resources, but it also causes these resources to be used less and thus lower efficiency (Méon and Weill, 2005). The fact that corruption causes imposition of unpredictable taxes that harm the efficiency of production can be given as a striking example (Campos et al., 1999). Many countries that have weak regulations levy high indirect taxes on agriculture and pursue protectionist

\footnotetext{
1 The method developed by Kaufmann et al. (Kaufmann et al., 2006a) is based on the perceptions of numerous data sources about governance and is divided into six sections: Data sources are firms, individuals, commercial risk rating institutions, civil society organizations and multinational aid organizations. The data consists of totally 276 variables and measures the different dimensions of governance. They were obtained from 31 different sources produced by 25 different institutions.
} 
policies. Krueger et al. (Krueger et al., 1991), in their study conducted with a data set including the period of 1960-1983 for 18 countries, found that indirect taxes on agriculture that stem from non-marketfriendly macroeconomic policies are three times higher than direct taxes and that they have a disincentive effect for production. Second, bad governance and especially corruption encourage transfer activities, deviate efficient practices, and thus create low agricultural efficiency. Most resources in a society in which corruption is widespread are allocated to rents rather than productive activities. Land management units are generally the government institutions where the highest degree of corruption is observed; and therefore they obstruct agricultural development (World Bank, 2008). Third, agricultural production efficiency is affected by the qualities and quantities of public goods and services such as roads, irrigation systems, communication infrastructure, schooling, agricultural research and widespread programs. A more "efficient government" provides public goods and services better. Political instability, on the other hand, influences the characteristics of public investments. Administrators in powerful countries canalize public goods into investment in order to support log-term growth. In weaker countries, on the other hand, administrators tend to redistribute the available resources based on bribes, and they mind the short-term rather than the long-term as they lack widespread popular support (Moe, 1990). Fourth, governance influences agricultural efficiency based on political outcomes; which are determined through agricultural relations, taxes, subsidies, allocation of public goods and political negotiations between interest groups. More "accountability" increases transparency and shifts political, financial and administrative power from central to local administrations. This situation changes the nature of political participation and encourages the participation of hitherto-powerless agricultural groups. Therefore, we hypothesize that countries with good governance indicators have high efficiency in agriculture.

H1a: countries with pervasive corruptions have less efficiency in agriculture.

H1b: countries with effective governments have high efficiency in agriculture.

H1c: countries with strong voice and accountability measures have high efficiency in agriculture

H1d: countries with high regulatory qualities have high efficiency in agriculture

However, in some cases, bad governance might create higher efficiency whereas good governance might cause low efficiency. The best known example is the "Grease the Wheels" hypothesis. Corruption in countries with slow and ineffective bureaucracies might enhance productivity (Huntington, 1968). Moreover, intellectual property rights might accelerate technology transfer (Méon and Weill, 2005). Political stability does not always bring about economic efficiency, because most reforms that accelerate economic efficiency have been made in crisis times (Binswanger and Deininger, 1997). Stigler (Stigler, 1951) links the ability to exploit modern agricultural methods and development to the presence of wide networks of exchange that support the use of inputs such as machinery and chemical fertilizers and the division of labour. Studies have been carried out on the production differences between farmers in poor and rich countries. Why can farmers of poor countries not produce like their counterparts in rich countries? Schultz (Schultz, 1964) argues that farmers in poor countries are poor but efficient. The reason lying beneath the inability of farmers, who can rationally allocate available resources, to attain high productivity is the inadequate supply of modern agricultural technologies in poorer countries. Ruttan (2002) suggests that, in order to enhance agricultural productivity, developing countries should increase the capacities of agricultural research institutions and the volume of their technological investments as well as increasing the schooling rate and popularizing education in rural areas. As we hypothesize,

H2: higher levels of investments in R \$D lead to higher levels of efficiency in agriculture. H3: higher levels of investments in education lead to higher levels of efficiency in agriculture.

According to recent studies, even if a country possesses the potential to develop and use modern technologies, economic productivity might still remain low if research institutions are not effective and expedient. Olson (1996) argues that many poor countries only waste money and resources, since they lack expertise and sufficient institutional framework to fully comprehend the profits of trade. Due to institutional failures, individual rational behaviours can cause social inefficiencies. Agricultural exports are the external factors that affect the ability of agricultural productivity that helps to compete in the international markets. One of the expectations from trade liberalization is productivity gains. Markheim (2007) argues this issue; "Free trade allows a country to compete in the global market according to its fundamental economic strengths and to reap the productivity and efficiency gains that promote long-run wealth and prosperity." A country`s competitiveness is assessed through its exporting ability. Countries with efficient agricultural producers are expected to be food exporters. Consequently agricultural efficiency is concerned with open access to foreign markets. 
H4: countries with the higher share of agricultural products in exports have higher agricultural efficiency. H5: countries with the higher share of food products in exports have higher agricultural efficiency.

\section{Methodology}

In this study, Data Envelopment Analysis (DEA), Malmquist Index (MI) and regression analysis were employed. Data gathered from World Development Index database. We find agricultural efficiency scores and efficiency changes between 1993 and 2006 of 24 EU countries with DEA and MI in the first stage. Then, using the efficiency scores of the countries and factors that were collected from literature to be affecting agricultural efficiencies a panel regression analysis was executed. Since data were fully available only between 2003 and 2006, in the second stage a four years period was used for panel regression. In what follows, these methods will be explained briefly along with relevant analyses and comments.

Data Envelopment Analysis: DEA is a non-parametric method that is based on linear programming and aimed at measuring Decision Making Units' (DMUs) relative efficiencies with respect to one or more input and output values (Charnes et al., 1994). In case there is one input and one output, ratio analysis can be used to compare DMUs. However, when the number of inputs and outputs is more than one or the inputs and outputs are in different scales, ratio analysis is not applicable. DEA steps in here, because it enables the evaluation of multiple inputs and multiple outputs together even if they are in different scales. For DEA, no functional situation is needed between inputs and outputs other than linearity, and units are compared based not on the means but on the most efficient units. DEA's relative efficiency evaluation can be summarized as follows: It defines "the best" observations, which produce the highest amounts of output using the lowest amounts of input within a given observation cluster, as the decision making units that constitute the efficiency frontier. Taking the efficiency frontier as the "reference", it measures the distances of inefficient units to it and determines their efficiency levels out of 1 .

DEA method can be employed in two types: input-oriented and output-oriented. While the former investigates the combination of inputs that is required to obtain a certain output level, the latter attempts to determine the combination of outputs that is necessary to have a certain combination of inputs. The general formulation of DEA model can be illustrated as follows:

Efficiency $=$ Weighted sum of outputs $/$ Weighted sum of inputs

Suppose that " $n$ " number of units have " $m$ " number of inputs and " $s$ " number of outputs. The efficiency of p-th unit can be calculated as follows, based on what Charnes et al. (1978) suggest:

$$
\begin{aligned}
& \operatorname{Max} \frac{\sum_{k=1}^{s} v_{k} y_{k p}}{\sum_{j=1}^{m} u_{j} x_{j p}} \\
& \sum_{k=1}^{s} v_{k} y_{k i} / \sum_{j=1}^{m} u_{k} x_{j i} \leq 1 ; \quad \forall i \\
& v_{k}, u_{j} \geq 0 ; \quad \forall k, j \\
& \mathrm{k}=1 \ldots \mathrm{s}, \mathrm{j}=1 \ldots \mathrm{m}, \mathrm{i}=1 \ldots \mathrm{n}, \\
& y_{k i}=\text { amount of k-th output yielded by i-th unit, } x_{j i}=\text { amount of } \mathrm{j} \text {-th input used by } \mathrm{i} \text {-th unit, } v_{k}=\text { weight } \\
& \text { of k-th output, } u_{j}=\text { weight of } \mathrm{j} \text {-th input. }
\end{aligned}
$$

Objective function is the maximization of the ratio of weighted outputs to weighted inputs. Constraints, on the other hand, is for the ratio of weighted outputs to weighted inputs to be less than or equal to 1 .

The linear programming model above is written for each DMU separately and is run $\mathrm{n}$ times. The result obtained for each unit is its efficiency score. In order to maximize the efficiency of each unit, amounts of inputs and outputs are weighted properly. While units with efficiency score of 1 is labelled as "efficient", those with efficiency scores below 1 are named "inefficient units". Inefficient units can be ranked on the basis of efficiency scores. In addition, through DEA, reasons and extents of relative inefficiencies of inefficient units can be determined. 
Total Factor Productivity and Malmquist Index: In order to demonstrate the changes in efficiencies over time, the changes in total factor productivities are examined using Malmquist index, which is formulated as follows:

TFPC $=$ TEC $\times$ TC

TEC $=$ SEC $\times$ PEC

Total Factor Productivity Change (TFPC): It explains the changes in Technical Efficiency and Technology together. It refers to the sum of the productivities of all factors of production involved in the production process.

Technical Efficiency Change (TEC): It is the change that occurs under the assumption of constant returns to scale. It is defined as the ratio of the highest amount of output that is obtained using the best production techniques to the actual amount of output.

Technological Change (TC): It refers to the change in the level of technology employed.

Scale Efficiency Change (SEC): It shows whether the organization has reached up to the most efficient volume of production.

Pure Efficiency Change (PEC): It is the change in technical efficiency under the assumption of variable returns to scale (Thanassoulis, 2001).

The formula of Malmquist Index is as follows:

Technical Efficiency Change $=\frac{d_{0}^{t+1}\left(x^{t+1}, y^{t+1}\right)}{d_{0}^{t}\left(x^{t}, y^{t}\right)}$

Technological Change $=\left[\frac{d_{0}^{t}\left(x^{t+1}, y^{t+1}\right)}{d_{0}^{t+1}\left(x^{t+1}, y^{t+1}\right)} \times \frac{d_{0}^{t}\left(x^{t}, y^{t}\right)}{d_{0}^{t+1}\left(x^{t}, y^{t}\right)}\right]^{1 / 2}$

Total Factor Productivity Change

$=\frac{d_{0}^{t+1}\left(x^{t+1}, y^{t+1}\right)}{d_{0}^{t}\left(x^{t}, y^{t}\right)} \times\left[\frac{d_{0}^{t}\left(x^{t+1}, y^{t+1}\right)}{d_{0}^{t+1}\left(x^{t+1}, y^{t+1}\right)} \times \frac{d_{0}^{t}\left(x^{t}, y^{t}\right)}{d_{0}^{t+1}\left(x^{t}, y^{t}\right)}\right]^{1 / 2}$

(Färe, et al., 1994).

In order to determine the changes in efficiencies of countries over time, changes in total factor productivities are examined using Malmquist index. If the change in the total factor productivity of a country is on the rise, then TFPC $>1$. If the change in the total factor productivity of a country is on the decline over time, then TFPC $<1$.

\section{Results}

In the study, data of $23 \mathrm{EU}$ countries and Turkey were used. Data gathered from World Development Index database. The EU countries of which data are fully available without missing values were included in the analysis. At the first stage, efficiencies and TFPC of 24 countries were analyzed. The model consists of four inputs and one output. Whereas the inputs are agricultural areas (square $\mathrm{km}$ ), number of tractors, amount of fertilizers consumed (ton) and amount of labour, the output is the value added created in agriculture in USD (in 2000 fixed prices). The data were obtained from the World Development Index database. Countries' technical efficiency mean scores are given in Table 1. Based on the technical efficiency results; best performing countries are the Netherlands and Finland, while the countries with the worst performance are Poland, Lithuania and Latvia. 
Table 1: Countries' technical efficiency means scores

\begin{tabular}{llllllll}
\hline \multicolumn{2}{l}{ Countries' Technical Efficiency Mean Scores } & & & & \\
Austria & Bulgaria & Cyprus & $\begin{array}{l}\text { Czech } \\
\text { Rep. }\end{array}$ & Denmark & Finland & France & Germany \\
\hline 0,770 & 0,670 & 0,861 & 0,439 & 0,900 & 1,000 & 0,888 & 0,486 \\
Greece & Hungary & Italy & Lithuania & Netherlands & Poland & Portugal & Romania \\
0,989 & 0,541 & 0,943 & 0,349 & 1,000 & 0,347 & 0,836 & 0,841 \\
Slovak & Slovenia & Spain & Sweden & Turkey & England & Ireland & Latvia \\
Rep. & 0,516 & 0,786 & 0,883 & 0,886 & 0,503 & 0,972 & 0,413 \\
0,899 & & & & &
\end{tabular}

The total factor productivity change (TFPC) values calculated for a total of 24 countries were examined under the assumption of constant returns to scale (CRS) (Table 2). A TFPC index value higher than 1, points to a rise in TFPC, while a value lowers than 1 indicates a decline. The same is also true for technical efficiency change (TEC) technological change (TC) index values. In other words, for the TEC index to have a value higher than 1 refers to the catch up effect (for the country to catch up with the production frontier); and for the TC index to have a value higher than 1 means an upward movement in the production frontier. The results suggest that 24 countries made a progress in TFPC (average of countries and years is 1,024). Similarly, since the mean values of TEC and TC indexes are higher than 1 (TEC: 1,013 and TC: 1,014), it could be concluded that a technical and technological progress was made in these years.

Table 2: Malmquist index results with its components

\begin{tabular}{|c|c|c|c|c|c|c|c|}
\hline Country & $\begin{array}{l}\text { Catch- } \\
\text { up } \\
\text { Average }\end{array}$ & $\begin{array}{l}\text { Frontier } \\
\text { Average }\end{array}$ & $\begin{array}{l}\text { Malmquist } \\
\text { Average }\end{array}$ & Country & $\begin{array}{l}\text { Catch- } \\
\text { up } \\
\text { Average }\end{array}$ & $\begin{array}{l}\text { Frontier } \\
\text { Average }\end{array}$ & $\begin{array}{l}\text { Malmquist } \\
\text { Average }\end{array}$ \\
\hline Austria & 0.972 & 1.011 & 0.984 & Portugal & 0.974 & 1.030 & 1.003 \\
\hline Bulgaria & 1.004 & 1.039 & 1.043 & Romania & 1.039 & 1.039 & 1.068 \\
\hline Cyprus & 0.987 & 1.026 & 1.003 & Slovak Republic & 1.041 & 1.035 & 1.072 \\
\hline Czech Republic & 0.966 & 1.022 & 0.979 & Slovenia & 0.991 & 1.012 & 0.999 \\
\hline Denmark & 1.023 & 1.001 & 1.023 & Spain & 1.006 & 0.990 & 0.994 \\
\hline Finland & 1.008 & 0.997 & 1.006 & Sweden & 1.025 & 1.021 & 1.038 \\
\hline France & 1.018 & 0.993 & 1.011 & Turkey & 1.012 & 0.994 & 1.004 \\
\hline Germany & 1.019 & 1.016 & 1.012 & United Kingdom & 0.993 & 1.042 & 1.024 \\
\hline Greece & 0.972 & 1.000 & 0.972 & Ireland & 0.976 & 0.992 & 0.968 \\
\hline Hungary & 1.022 & 1.004 & 1.026 & Latvia & 1.268 & 1.034 & 1.319 \\
\hline Italy & 1.019 & 1.011 & 1.029 & & & & \\
\hline Lithuania & 0.973 & 1.006 & 0.976 & Average & 1.013 & 1.014 & 1.024 \\
\hline Netherlands & 1.016 & 1.019 & 1.036 & Max & 1.268 & 1.042 & 1.319 \\
\hline Poland & 0.995 & 1.003 & 0.996 & Min & 0.966 & 0.990 & 0.968 \\
\hline
\end{tabular}

At the second stage, factors that define countries' agricultural efficiencies namely; voice and accountability, control of corruption, government effectiveness, regulatory quality, education, research and development expenditures, agricultural exports which reflects countries' openness to the external world were analyzed using panel regression. Since the number of countries in the analysis was not suitable for random effects or fixed effects panel regressions, pooled panel regression analysis was employed. Since the dependent variable efficiency was restrained between 0 and 1, Tobit panel regression analysis was applied. It was attempted to examine the impact of the above-defined six factors upon the countries' agricultural efficiencies for the period of 1993-2006 through Tobit panel regression analysis. However, the years between 1993 and 2002, for which data were mostly missing, could not be included in the analysis. It therefore covers four years of the period of 2003-2006 (Table 3).

The relationships were examined between the efficiency scores of $24 \mathrm{EU}$ countries for the years between 2003 and 2006 and the governance indicators with control variables used in the model; which were government effectiveness (captures perceptions of the quality of public services, the quality of the civil service and the degree of its independence from political pressures, the quality of policy formulation and 
implementation, and the credibility of the government's commitment to such policies), regulatory quality (captures perceptions of the ability of the government to formulate and implement sound policies and regulations that permit and promote private sector development), control of corruption (captures perceptions of the extent to which public power is exercised for private gain, including both petty and grand forms of corruption, as well as "capture" of the state by elites and private interests), voice and accountability index (captures perceptions of the extent to which a country's citizens are able to participate in selecting their government, as well as freedom of expression, freedom of association, and a free media), (see [33]), the share of education expenses in GDP (expen.edu), the share of expenditures per student in GDP (expendperstud), the share of research and developments expenditures in GDP (R\&D), the share of agricultural products in exports (agrexport) and the share of food products in exports (food export).

Table 3: Tobit Regression Results (2003-2006)

\begin{tabular}{lcclc}
\hline Efficiency & B & St. Dev. & \multicolumn{1}{l}{ T } & P>t \\
\hline Gov.effective & -0.340 & 0.233 & -1.46 & 0.147 \\
Regul.quality & -0.253 & 0.201 & -1.26 & 0.213 \\
Cont.corrup & 0.181 & 0.148 & 1.23 & 0.224 \\
Voice.account & 0.453 & 0.193 & 2.35 & 0.021 \\
Expen.edu & -0.214 & 0.050 & -4.29 & 0.000 \\
Expenperstud & 0.005 & 0.004 & 1.30 & 0.196 \\
R\&D & 0.307 & 0.089 & 3.43 & 0.001 \\
Agrexport & 0.009 & 0.010 & 0.88 & 0.379 \\
Foodexport & 0.022 & 0.006 & 3.53 & 0.001 \\
Constant & 1.103 & 0.167 & 6.61 & 0.000 \\
N & 85 & & & \\
LR chi2 & 32.9 & & & \\
Prob > chi2 & 0.000 & & & \\
Log likelihood & -24.03 & & & \\
Pseudo R2 & 0.406 & & & \\
\hline
\end{tabular}

According to the analysis results; the impact of the share of GDP allocated to education on agricultural efficiency is negative, whereas the impacts of voice and accountability, the share of R\&D in GDP and the share of food products in exports on the agricultural efficiency are positive. Other variables had no significant - positive or negative- impacts on the efficiency. It could therefore be stated that as the share of food exportation in total exports and the share of R\&D in GDP increase, the country's agricultural efficiency increases; however a rise in the share of education in GDP decreases the country's agricultural efficiency.

\section{Conclusion}

Agriculture is of priority for economic development. There exists a positive correlation between agriculture and development. In this respect, for development in agriculture industry technology and policies implemented are of as much importance as land. In this study, the efficiencies of the agriculture industries of Turkey and 23 EU countries were comparatively analyzed. Firstly using Data Envelopment Analysis; efficiencies of countries' agriculture industries, their technical efficiency levels, technical efficiency changes, technological changes and total factor productivity changes were calculated. According to technical efficiency index results, best performers are the Netherlands and Finland (TE=1). These two countries were followed by Greece, Ireland, Italy, Denmark, Slovakia, France, Turkey, Sweden, Cyprus, Romania, Portugal, Spain, Austria, Hungary, Bulgaria, Slovenia, England, Germany, Czech Republic, Latvia, Lithuania and Poland, respectively. In other words, the country that exhibited the worst performance is Poland. Other than a couple of countries; the technical efficiency, technological change and total factor productivity indexes of all countries rose. Secondly, panel regression analysis was employed in order to examine the relationship of countries' agricultural efficiencies and countries' voice and accountability, government effectiveness, regulatory quality, control of corruption, R\&D resources, 
education resources and openness to the outside (the share of agricultural products in exports and the share of food products in exports). Since the number of countries was low, pooled panel data analysis was preferred. According to the results obtained; the impact of the share of GDP allocated to education upon agricultural efficiency is negative, whereas the impacts of voice and accountability, the share of R\&D in GDP and the share of food products in exports upon the agricultural efficiency are positive.

If a countries' agriculture industry is traditional and not perfectly competitive, farmers are unable to market their products. Prices are not determined under perfectly competitive conditions and intermediaries exploit the situation. Therefore to improve efficiency in agricultural industry it is necessary to improve export connections and to render the markets efficient. It is much more important for the policy-makers in agriculture to take the necessary measures and to make the structural changes in order to open the agriculture industry to the outside world and to endow it with competitive market conditions by getting rid of its traditional formation than the direct supports provided to the industry. One of the important elements required for increasing the productivity of agriculture is to ensure the safety of property rights and to provide to farmers an environment in which investment returns are very well protected. Institutional framework plays an incentive role for farmers to utilize their resources efficiently. The sense of citizenship strengthened by rule of law reduces rent-seeking activities (North, 1990). Harvey (2004) argued that three main factors increase the political pressure towards government interventions and protection over the agriculture industry. The first is the Engel's law; which suggests that as the economic process advances the relative importance of agriculture decreases and the political pressure for protection increases (De Gorter and Tsur, 1991). The second one is the idea that agricultural products are indispensable for survival and prosperity. The last one is that, due to the divisible nature of the agriculture industry, producers earn more from political manipulations compared to market competition.

Stigler (1951) links the ability to exploit modern agricultural methods and development to the presence of wide networks of exchange that support the use of inputs such as machinery and chemical fertilizers and the division of labour. For these factors to be realized, it is underlined that there exists a need for experts who will accomplish development and for the sustainability of specialized inputs. For such a large and complex network of exchange, it is not enough alone to try to make progress through tradition, culture and social pressure. For change, there exists a need for a law of contracts and for a just constitutional system, which is the basis of a democratic society. The notion of governance that provides the required institutions for efficient development has a significant impact upon a country's agricultural production efficiency. For example, Hayami and Rutan (Hayami and Ruttan, 1985) maintained that weak institutions and policies vitiate both the adaptation of appropriate technologies and the influence of organized innovations. In the World Development Report in 2008 (World Bank 2008), it was suggested that governance is the basis of agricultural development and that the process of democratization, participation of civil societies, public sector administrative reforms and control of corruption pose a great potential for enhancing agricultural productivity.

\section{References}

Adebayo, J., Christopher, M. C. K., Thorpe, J. \& Kazamel, M. (2014). Food and Agriculture Organization of the United Nations Background Guide 2015, 1-52. http://www.nmun.org/ny15_downloads/BGGs/NY15_BGG_FAO.pdf.

Adkins, L. C., Moomaw, R. L. \& Savvides, A. (2002). Institutions, Freedom and Technical Efficiency. Southern Economic Journal, 69, 92-108.

Arnade, A. C. (1994). Using Data Envelopment Analysis to Measure International Agricultural Efficiency and Productivity. United States Department of Agriculture, Economic research service, Technical Bulletin, US, No. 1831.

Bayyurt N. \& Yılmaz, S. (2012). The Impacts of Governance and Education on Agricultural Efficiency: An International Analysis. Procedia - Social Behaviour Sciences, 58, 1158 - 1165.

Binswanger, H. \& Deininger, K. (1997). Explaining Agricultural and Agrarian Policies in Developing Countries. Journal of Economic Literature, 35, 1958-2005.

Campos, J. E., Lien, D. \& Pradhan, S. (1999). The Impact of Corruption on Investment: Predict Ability Matters. World Development, 27, 1059-1067.

Charnes, A., Cooper, W. W. \& Rhodes, E. (1978). Measuring the Efficiency of Decision Making Units. European Journal of Operational Research, 2(6), 429-444. 
Charnes, A., Cooper, W. W., Lewin, A. Y. \& Seiford, L. M. (1994). Data Envelopment Analysis: Theory, Methodology, and Applications. Boston: Kluwer.

Çakmak, E., Dudu, H. \& Öcal, N. (2008). Efficiency in Turkish Agriculture and a Quantitative Analysis (Turkish). Ankara: TEPAV.

Davidova, S. M., Gorton, M., Ratinger, T., Zawalinska, K. \& Iraizoz, B. (2005). Farm Productivity and Profitability: A Comparative Analysis of Selected New and Existing EU Member States. Comparative Economic Studies, 47(4), 652-674.

De Gorter, H. \& Tsur, Y. (1991). Explaining Price Policy Bias In Agriculture: The Calculus of SupportMaximising Politicians. American Journal of Agricultural Economics, 73(4), 1244-1254.

Deliktaş, E., Ersungur, S. M. \& Candemir, M. (2005). The Comparison of Agricultural Efficiency and Productivity Growth in the EU and Turkey, 1980-2002. International Journal of Business, Management and Economics, 1, 109-124.

European Commission. (2014). Overview of CAP Reform 2014-2020. Agricultural Policy Perspectives Brief, No.5, December 2013: 1-10. http://ec.europa.eu/agriculture/policy-perspectives/policybriefs/05_en.pdf.

Färe, R., Grosskopf, S., Norris, M. \& Zhang, Z. (1994). Productivity Growth, Technical Progress and Efficiency Changes in Industrialised Countries. The American Economic Review, 84, 66-83.

Harvey, D. R. (2004). Policy Dependency and Reform: Economic Gains versus Political Pains. Agricultural Economics, 31, 265-275.

Hayami, Y. \& Ruttan, V. (1985). Agricultural Development: An International Perspective. Baltimore, MD: Johns Hopkins University Press.

Huntington, S. P. (1968). Political Order in Changing Societies. New Haven, CT: Yale University Press.

Kaufmann, D., Kraay, A. \& Mastruzzi, M. (2006a). Governance Matters III: Governance Indicators for 19962005. World Bank Policy Research Working Paper, WPS 3106 Washington, D.C, World Bank.

Kaufmann, D., Kraay, A. \& Mastruzzi, M. (2006b). Governance Matters V: Aggregate and Individual Governance Indicators for 1996-2005. World Bank Policy Research Working Paper, WPS 4012, Washington, D.C.: World Bank.

Kaya, A. \& Avcl, M. A. (2008). Efficiency and Total Factor Analysis in Transition Economies and Turkish Agriculture 1992-2004. Ege Academic Review, 8, 843-860.

Krueger, A., Schiff, M. \& Valdes, A. (1991). A. Political Economy of Agricultural Pricing Policy. Baltimore, MD: Johns Hopkins University Press.

Lio, M. C. \& Hu, J. L. (2009). Governance and Agricultural Production Efficiency: A Cross-Country Aggregate Frontier Analysis. Journal of Agricultural Economics, 60, 40-61.

Markheim, D. (2007). Renew Trade Promotion Authority Backgrounder. The Heritage Foundation Press, No. 2014, March 8.

Marković, K., Njegovan, N. \& Pejanović, R. (2012). Former and Future Reforms of Common Agricultural Policy of the European Union. Economics of Agriculture, 59(3), 483-498.

Méon, P. G. \& Weill, L. (2005). Does Better Governance Foster Efficiency? An Aggregate Frontier Analysis. Economics of Governance, 6, 75-90.

Minh N. K. \& Long, G. T. (2008). Factor Productivity and Efficiency of the Vietnamese Economy in Transition. Asia-Pacific Development Journal, 15(1), 93-117.

Moe, T. M. (1990). Political Institutions: The Neglected Side of the Story. Journal of Law, Economics, \& Organization, 6, 213-253.

North, D. (1990). Institutions, Institutional Change and Economic Performance. New York: Cambridge University.

Olson, M. (1996). Big Bills Left on the Side Walk: Why Some Nations are Rich, and Others Poor. Journal of Economic Perspectives, 10, 3-24.

Ruttan, V. (2002). Productivity Growth in World Agriculture: Sources and Constraints. Journal of Economic Perspectives, 16, 161-184.

Schultz, T. (1964). Transforming Traditional Agriculture. New Haven, CT: Yale University Press.

Serrao, A. (2003). Agricultural Productivity Analysis of European Union and Eastern Regions. American Agricultural Economics Association Annual Meeting, Motreal, Canada.

Stigler, J. (1951). The Division of Labor is limited by the Extent of the Market. Journal of Political Economy, $59,185-194$.

Thanassoulis, E. (2001). Introduction to the Theory and Application of Data Envelopment Analysis: A Foundation E Text with Integrated Software. Kluwer Academic Publishers: Boston.

World Bank. (2008). World Development Report 2008: Agriculture for Development. Washington D.C., World Bank. 
World Bank. (2014). Worldwide Governance Indicators. http://info.worldbank.org/governance/wgi/index.aspx\#doc.

Zaim, O., Bayaner, A. \& Kandemir, M.U. (2001). Productivity and Efficiency Between Regions and Cities: Differences and Reasons. Republic of Turkey Ministry of Food, Agriculture and Livestock. No: 66, Ankara, TEAE. 